Article

\title{
The Anthropocenic Turn: Theorizing Sustainability in a Postnatural Age
}

\author{
Manuel Arias-Maldonado
}

Received: 30 October 2015; Accepted: 30 November 2015; Published: 24 December 2015

Academic Editor: Md Saidul Islam

Área de Ciencia Política, Facultad Derecho UMA, University of Málaga, Campus Teatinos s/n., Málaga 29071, Spain; marias@uma.es; Tel.: +34-615-31-78-13

\begin{abstract}
So long as sustainability represents the attempt to pacify the relationship between societies and their natural environments, the concept must remain attentive to any findings about the character of such relation. In this regard, the rise of the Anthropocene cannot be ignored by environmental sociologists if a realistic understanding of sustainability is to be produced. The Anthropocene is a scientific notion, grounded on geology and Earth-system science, that plausibly suggests that human beings have colonized nature in a degree that has irreversibly altered the functioning of planetary systems. As a result, social and natural systems have become "coupled". This paper tries to elucidate the consequences that an "Anthropocenic turn" would have for sustainability studies. To such end, it will explore the related notions of hybridity and relational agency as key aspects of a renewed view of nature. Correspondingly, it argues that cultivated capital (rather than natural or manmade) must be the most important unit for measuring sustainability and devising sustainable policies in a postnatural age.
\end{abstract}

Keywords: sustainability; environmental sociology; Anthropocene; nature; conservation; hybridity; socioecological metabolism; technology

\section{Introduction}

Sustainability has been defined in many different ways throughout the years, but it seems fair to assume that it can be said to represent the attempt to pacify the relationship between a society and its natural environment-irrespective of the way in which the subsequent pacification is pursued. Of course, there is no single definition of sustainability, but, more importantly, there is no single way of being sustainable either: socionatural relations possess a plasticity that allow for a number of possibilities depending, for instance, on the amount of natural capital (as opposed to manmade capital) to be preserved or the reliance on technological solutions. Hence the ideological clashes around this seemingly technical concept. However, the study of sustainability must remain attentive to any findings on the character of socionatural relations. This is why environmental sociologists cannot ignore the rise of the Anthropocene if a realistic understanding of sustainability is to be produced. Such is the subject of this paper.

However, what is the Anthropocene? Broadly speaking, it is a geological concept that tries to capture the change experienced in socionatural relations on a global scale after human activity has exerted a huge influence on natural systems for millenia. The term itself suggests that the Holocene is over: we would now be living in a new geological age due to our impact on the natural environment [1]. As an overarching scientific notion, grounded on geology and Earth-system science, it thus plausibly suggests that human beings have colonized nature in a degree that has irreversibly altered the functioning of planetary systems. 
Yet two different meanings can be discerned. On the one hand, the Anthropocene is a given historical period during which certain events have taken place. On the other, the Anthropocene is a result, the consequence of those socionatural events and processes. In other words, it is both a chronology (marked by the anthropogenic influence on natural systems during time) and a given state of relations between society and nature. One that, in fact, blurs their separation.

Needless to say, such a hypothesis resonates strongly as far as sustainability is concerned: as a general principle and as a particular technique that implements the latter in a given fashion. Scientists are suggesting that natural and social systems are now coupled, since the extent of the anthropogenic influence on ecological systems and natural processes is unprecedented [2,3]. This shift knows a large number of manifestations, among which climate change is surely the most popular one. But others, from urbanization to desertification, from species invasion to species extinction, must be added. Synthetic biology and growing genetic experimentation will just make this list longer. That is why, even if geologists do not give official recognition to the new geological epoch, this complex reality is not going to disappear. The Anthropocene is here to stay and environmental sociology has to take it seriously, especially when dealing with sustainability.

After all, the Anthropocene seems to confirm that society and nature are not two separate entities influencing each other, rather there exists a socionatural entanglement-that is, an irreversible, complex, and increasingly hybrid socionatural system. However, paradoxically, this does not mean that there remains no separation between human beings and nature. Ironically, it is because we have separated ourselves from nature in a certain way throughout history that this deep entanglement has been produced. In fact, that very separation allows us to be aware of this entanglement and offers us the chance to re-arrange socionatural relations in a new, more refined way. It is the delusion of naturalness that fades.

It should be noted, however, that not everyone is convinced that we are entering into a new era. Not every geologist is a defender of the new chronology, to begin with. On the other hand, the Anthropocene may be seen as a way of advancing a capitalistic narrative of colonization and humanization, making abstract declarations about the role of "humanity" while sidelining more particular questions about the responsibility of particular human groups over others, or just as a continuation of the grand narratives of modernity that still hinders the realization of a more radical, ecocentric political agenda. However, the grounds on which the hypothesis of the Anthropocene rest are firm enough, irrespective of how the geological question will be answered. These critical objections should rather be seen as part of the discussion on the Anthropocene, even though a possible response to them is that the Anthropocene is in itself a way to frame socionatural relations that creates a biased discussion in the first place.

The Anthropocene poses indeed a number of questions. What are the implications for environmental sociology? How does the Anthropocene change environmental sociology's self-perception? Are there intellectual resources that the discipline can turn to in order to deal with this theoretical challenge? Moreover, what does the Anthropocene say about nature and socionatural relations, and how does it affect sustainability? This paper will try to answer to these interrogations in the following sections. It will suggest that the Anthropocene debate deeply affects-or should affect—how sustainability is conceived, perceived, and searched for.

The paper is structured as follows. Section 2 will begin by considering how should environmental sociology react to the Anthropocene and what are the resources that it can employ in dealing with it. A classical concept advocated by Marx, that of socionatural metabolism, later developed into that of socioecological metabolism in order to explain the particular relationship established between a given society and its physical environment, is defended. Section 3 will turn to sustainability, exposing the key question of substitutability, i.e., the degree in which natural capital may be replaced by manufactured capital. Section 4 suggests that this frame may be becoming obsolete, as the notion of natural capital loses its naturalness due to a general process of socionatural hybridization that, for this very reason, must be taken into account by sustainability 
studies. Finally, Section 5 ponders what exactly the impact of hybridization in our understanding of sustainability may be, suggesting that natural capital is doomed to lose prominence in favor of manufactured capital. At the same time, this will diminish the force of the service argument in defense of protecting natural capital, leaving moral arguments for the social desirability of such protection as the most decisive ones. Section 6 offers a conclusion.

\section{The Anthropocenic Turn in Environmental Sociology}

It is well-known that environmental sociology was born as a correction of the environmental deficit of classical sociology-a correction from within that however represents "a major departure from sociology's traditional neglect of environmental phenomena" [4]. According to this prevailing view, modern classical sociology stressed human exceptionalism and was consolidated around a humanistic worldview. For Catton and Dunlap, founding fathers of environmental sociology, this "old exemptionalist paradigm" was to be contrasted with the "new environmental paradigm" advanced by the new subdiscipline [5]. If classical sociology had been "constructed as if nature didn't matter" [6] rooted as it was in a "socio-cultural determinism" [7], environmental sociology was to put the environment in its center.

Three major theoretical risks derive from these assumptions-risks that to some extent have been confirmed in the practice of environmental sociology in the last decades, despite having also found resistance within the discipline. Firstly, the neglect of classical sociology, understood as an Anthropocenic enterprise oblivious to the presence of nature in social evolution-a neglect that does not only create an unnecessary antagonism between classical and environmental sociology but also made it difficult to find insights about the socionatural relation in the work of classical sociologists. Secondly, the rejection of socio-cultural determinism was easily turned into an ecological determinism that reduced the role of human agency within the socionatural relation and overvalued the strength of ecological constraints vis-à-vis human societies. In so many predictions, the latter were reduced to the condition of passive witnesses of an unavoidable ecological catastrophe, thus reducing the range of possibilities allowed in the socionatural interaction as well as the ability of human societies to shape its environment. In turn, this view exerted a major influence on sustainability, seen as a human retreat from nature rather than as a reflective continuation of a complex process of evolutionary adaptation that involve-in the case of the human species-the transformation of nature. Thirdly, in close connection to this, the role of human beings was diminished as the weakest part in the socionatural relation, a paradoxical position if we recall that the ecological crisis itself would have been provoked by human beings themselves in their meddling with natural systems throughout time. If anthropocentrism was strongly rejected, exemptionalism and exceptionalism too: there was nothing special about human beings, as they are a part of nature and remains linked to and dependent of the latter.

In hindsight, such unbalances are understandable. Environmental sociology had to compensate for a prevailing anthropocentrism - almost an anthropocentrism by default-that had marked the development of the discipline from the outset. Predictably, it has also been within the latter that those risks have been, if not avoided, signaled. As a result, environmental sociology has grown more and more sophisticated and is now ready to deal with the Anthropocene, which however represents a major challenge to some core assumptions of environmental sociology as has been practiced so far. If the assumptions behind the Anthropocene are taken seriously, it is plain to see how they do relate to the theoretical risks just mentioned-confirming that some amendments are in order within the discipline if it is to keep close to the reality of socionatural relations.

In this vein, it is revealing that the Anthropocene lends credit to those classical sociologists that did pay attention to socionatural relations and took into account the environmental factor as a key one in societal development. It does so in an unexpected way, namely, restoring the plausibility of human exceptionalism. If humans have turned into great forces in natural evolution and have transformed planetary systems while adapting to their environment, it cannot be denied that they belong to a 
species that, belonging to nature, separates itself from it. Human/nature dualism is not ontological, but historical [8]. Ironically, this separation involves a deeper integration of human beings into nature via the transformation of the latter, actually turned into human environment. This intimate relationship between human beings and nature, that happens also to be a deeply transformative one, was anticipated by Karl Marx [9] through his concept of "socio-ecological metabolism" (Stoffwechsel). If we read Marx's explanation under the new hermeneutical context provided by the Anthropocene, he appears clearly as a contemporary:

"Labour is, first of all, a process between man and nature, a process by which man, through his own actions, mediates, regulates and controls the metabolism between himself and nature. He confronts the materials of nature as a force of nature. He sets in motion the natural forces which belong to his own body, his arms, legs, head and hands, in order to appropriate the materials of nature in a form adapted to his own needs. Through this movement he acts upon external nature and changes it, and in this way he simultaneously changes his own nature. (...) It (the labor process) is the universal condition for the metabolic interaction (Stoffwechsel) between man and nature, the everlasting nature-imposed condition of human existence" (my emphasis) [9].

To some extent, then, the Anthropocene might help to revive the old sociological paradigm, or rather those aspects of it that are more helpful when the massive transformation of the environment is to be explained. A successful transformation, it should be added: as the ecological catastrophes announced by classical environmentalism have failed to materialize, contemporary environmental sociology has to consider the possibility that there is no collapse at hand, but rather a complex socionatural relationship that has be to regulated through sustainable policies not so much oriented towards a human retreat from nature (which is not feasible anymore given the reciprocal imbrication of social and natural systems) than towards a recognition of the multi-layered and hybrid nature of the socionatural entanglement. Marx's metabolic rift is not a flawless notion, but it points to the right direction: that of recognizing the transformative powers of human agency and the dynamic character of a relationship that ultimately responds to the particular way of being of the human species. As Bellamy Foster, commenting Marx, points out:

"The material exchanges and regulatory action associated with the concept of metabolism encompassed both 'nature-imposed conditions' and the capacity of human beings to affect this process" [10].

It should be noted that Marx, albeit capturing the essential features of the socionatural relation, failed to take some important aspects of it into account. On the one hand, human labor produces a number of unintended, unforeseen consequences that in turn come to affect "nature-imposed conditions", as climate change so clearly shows. Moreover, the Anthropocene itself, mostly a product of the industrial acceleration of economic growth, is one of those consequences. On the other, while recognizing ecological constrictions, Marx did not go far enough in recognizing nature's agency and the reciprocal character of the influence that humanity and nature exert on each other. However, he was quite interested in Darwin's theory and it is reasonable to think that he might have endorsed a Darwinian reading of the Anthropocene, i.e., one that explains socionatural history as the product of human exceptionalism.

Other thinkers concerned with the future of environmental sociology have also stressed the importance of metabolism and the nature/culture dichotomy, as well as the need to combine structural and cultural perspectives, emphasizing both the centrality of human subjects and the materiality of nature [11]. In the words of Frederick Buttel, a reasonable sociological approach must consider "both 'structure' and 'agency', and the material and the symbolic" [12]. To such end, environmental sociology is forced nowadays to make interdisciplinary contact with other disciplines beyond the realm of social sciences, if the Anthropocene challenge is to be met. That is what 
Fischer-Kowalski and Weisz do when looking for insights in anthropology and biology that may help to sustain their concept of "socioeconomic metabolism", in itself an elaboration of Marx's [13]. They search for a realistic account of socionatural relations, one that

"must take into consideration the possibility of biophysically relevant interactions between symbolic (cultural) systems and the material world that are historically variable and that are not compensated for by natural adaptation. This implies a conception of cultural evolution beyond anthropological adaptationism" [13].

As I have suggested elsewhere [14], there are currents of evolutionary theory that provide an explanation of human beings ways on Earth that meets these requirements and should not be overlooked by environmental sociologists. They may serve as underlying foundations for an environmental sociology that puts an updated notion of socionatural metabolism at its core. On the one hand, Historical Ecology claims that changes in socionatural relations are caused by history rather than evolution, focusing on the interaction between cultures and environments, the latter beinf adapted to societies and not the opposite way [15]. Human agency is thus fully recognized as a transformative force [16,17]. On its part, niche-construction theory holds that organisms do adapt to their environments changing them through a strategy of niche-construction that in the case of human beings is turbocharged by cultural accumulation and transmission [18-20]. That is why adaptationism should be reconsidered as a model for explaining human-environment relations, replacing it instead with a model that puts emphasis on a transformative human agency that is both the problem (creating the ecological crisis in the first place) and the remedy (providing solutions through a number of ways) [21].

Moreover, niche-construction theory, grounded as it is in the operations of human culture in a given environmental context, leaves room for recognizing that any socionatural interaction is socially bounded and culturally constrained. Instead of possessing unique features in any given time and space, socionatural relations vary relatively in different social settings, thus producing disparate "socio-ecological regimes" [22]. This is an advantage over rigidly anti-essentialist views of nature, since that plurality of regimes is encompassed under the broader context of a universal drive towards aggressive adaptation-a species drive. It should be added that this interplay between structure and variation belongs quite naturally to the province of sociology.

As a result, the universal human drive towards adaptation manages exhibits a good deal of variability, since the social re-construction of nature in which it consists leads to different socio-ecological regimes depending on local circumstances as much as on cultural representations. In fact, they interact continuously. However, it is also true that national and local societies are gradually converging around a "Western" Weltanschaaung that unifies values and technologies alike. Globalization and digiticization are accelerating this process, by which particular patterns of socionatural interaccion are being eroded.

Nevertheless, an important side-effect of the Anthropocenic narrative is the normalization of capitalism. By stressing the species ways of being rather than blaming particular episodes of human history, the Anthropocene suggest that the aggressive adaptation to the natural environment is a universal human drive, a permanent feature of socionatural relations-not a trait of capitalism or the particular effect of the capitalistic treatment of nature. The idea that capitalism "produces" nature, thus, is misleading [23]. It is true that, in Smith's own phrasing, "first nature" is replaced by an entirely different, produced, "nature". However, capitalism is an accelerator of an otherwise unavoidable process of human colonization and transformation of the environment, not its prime cause. Needless to say, the way in which capitalism "produces" nature merits research as a particular-and particularly intense—episode of a wider story [24].

Another feature of socionatural relations that the Anthropocene has reinforced and thus highlighted is hybridity. Environmental sociologists have claimed for long a time now that hybrids are the new normal in this realm, so that the discipline is now well-prepared for recognizing the 
degree in which this feature has been intensified in the Anthropocene. As Bruno Latour argued, hybrids do not fall into either of the competing categories of social or natural but instead weave together elements of both. Humans and non-humans cannot be separated anymore, rather they are embedded in networks where their respective boundaries become increasingly diffuse [25]. The social and the natural, in other words, should be seen as "actively generated co-constructions" [26]. Society and nature influence each other at all levels, making society a natural force as much as making nature a societal force [27]. The Anthropocene shows, in a number of ways, how difficult it has become to disentangle the natural and the social—but mostly because the natural has been colonized by the social, influenced by it, transformed in different degrees. There is no pure nature anymore, but different scales of "naturalness" depending on the particular history of a living being, a natural process, an ecosystem. Although society and nature are now coupled and they form actually a socionatural entanglement, social and natural agency should not be conflated: human actors are more powerful agents of change than natural actants. An Anthropocenic turn in environmental sociology must recognize the primacy of human transformative powers, both intentional and unintentional.

An environmental sociology for the Anthropocene age should then be one that, as Fischer-Kowalski and Weisz suggested seventeen years ago, should distinguish between two key processes of socionatural interactions: socioeconomic metabolism (refered to the material exchange between social and natural systems) and colonization of natural processes (that is, the intentional and unintentional alteration of natural beings and processes through different means) [13]. It is the extent to which this colonization has taken place that merits such a powerful label as the Anthropocene. Crucially, the recognition of human transformative powers involve a more open approach towards sustainability, namely, one that is not so concerned with technical limits to human action or social development but rather more interested in the discussion about the most desirable social organization vis-à-vis the natural environment. The plasticity of socionatural relations, which arguably was always greater than classical environmental sociology acknowledged, makes supposedly rigid ecological limits rather contestable. For instance, when Dunlap and Catton discuss the functions performed by ecosystems, they may well claim that "exceeding the capacity of a given ecosystem to fulfill one of the three functions may disrupt not only its ability to fulfill the other two, but also its ability to continue to function at all" [28], thus leading to ecological unsustainability and socionatural collapse-yet it debatable whether an ecosystem possesses anymore a fixed, unchangeable capacity, or whether this capacity can be altered, or stretched, through social intervention.

In sum, a postnatural environmental sociology, i.e., a sociology that undergoes an Anthropocenic turn, should then be grounded on the following premises:

(i) A recognition of the extent to which society has colonized nature, up to the point where the proposition that the latter has ended is not incongruous-if we understand this ending as the pervasive influence of society on nature. The most important result of such colonization is hybridization, the mixture of the natural with the social.

(ii) Nature and society thus form a socionatural entanglement, a reflection of their co-evolution and co-construction throughout history-a process, which, however, does not preclude the primacy of the human agency due to the potency of human transformative powers.

(iii) This process of colonization and transformation is in itself the product of the human species particular way of being, according to which there exists a universal drive towards adaptation that takes the form of an aggressive adaptation wherein the physical environment is transformed: a niche-construction process that in the case of humans is accelerated by cultural transmission and admits, despite its universality, regional and local variations.

(iv) Socionatural relations are thus expressed through a number of socio-ecological regimes that organize them in different settings, depending on the way in which each society relates itself with its natural environment (type of socionatural metabolism, degree and forms of colonization, system of beliefs). Globalization, economic growth and the diffusion of technology are increasingly reducing those differences in the Anthropocene age. 
(v) This means that socionatural relations are not marked by the logic of limits emphasized by classical environmentalism and early environmental sociology, but defined on the contrary by a plasticity that is scientifically and technologically enforced. As a result, there is no single sustainability, but a plurality of potential sustainabilities—or sustainable socioecological regimes-depending on what value choices are made when deciding which is the most desirable relationship with natural systems, forms and beings.

As Field et al. have noted, much environmental sociology is done in a "grand theory" mode, reflecting a tendency to approach the environment in relatively general terms rather than seeing it as endowed with particular features that vary in different settings with consequences for populations or communities [29]. Ideally, an environmental sociology for the Anthropocene should be able to combine both perspectives, so that middle-range work supports and illuminates what grand theories have to say. This is especially the case in the field of sustainability studies, where a delicate balance has to be achieved wherein theoretical insights are not made in an empirical vacuum, while at the same time the latter do not impose an straitjacket on sociological imagination, all the more now that technological acceleration opens up new perspectives on what is technically possible in this realm with alarming speed.

If we turn our attention to sustainability, the question is: How does a postnatural understanding of nature affect it? Why is the Anthropocene a game-changer that makes old views on the subject obsolete and forces environmentalism to reframe the sustainability question, abandoning survivalism in favor of a vision of the good sustainable society? The key question concerns how substitutability—-the core concept in advanced notions of sustainability-is affected by increasing hybridity.

\section{The Substitutability Question}

Once a powerful but ultimately vague notion associated with issues of social justice and fair economic development, sustainability has become a complex and refined concept that revolves around a number of neatly identified issues-from different forms of capital to ecosystem services. Information technologies are helping to make more precise measurements and to monitorize the outcomes of environmental policies and conservation programs. At the same time, sustainability has been relocated into a wider framework, namely, the social response to global warming-in itself another, yet the most spectacular, manifestation of the Anthropocene. Therefore, sustainability is linked to strategies of mitigation and adaptation that emphasize the consumption of energy and the production of food for an increasing population as key aspects of any sustainable global society. For classical environmentalists, sustainability is still a tool for political transformation, yet the association between sustainability and a radically democratized, postcapitalistic, frugal society is weaker than ever. In fact, climate change and the related notion of the Anthropocene expose the flaws of the classical green view of sustainability.

In this regard, social justice used to be seen as an important basis for sustainability [30], but, despite the usefulness of multi-dimensional approaches and the political attraction that exerts its association to human development [31,32], it is fair to say that socionatural patterns of interaction are now considered the most relevant indicator for identifying different modes of sustainability. After all, if every sustainable society must operate according to a particular socioecological regime [13], it makes sense to focus on the way in which the socionatural interaction is to be dealt with.

Essentially, what has to be decided in each case-but also globally if problems such as climate change are to be tackled-is how much nature must be protected. Or, in other words, the degree to which natural capital is to be substituted by human-made capital. How much natural capital can be substituted becomes thus the key question. In other words, we have to decide how to keep a sufficient pool of resources irrespective of whether we are willing to preserve nature for its own sake, to pass on a high level of welfare to future generations, or to avoid climate apocalypse. Such reasons are technically irrelevant, although they are of course politically crucial. 
Introduced by economists in the early 1990s [33,34], the concept of capital natural has become a key one insustainability studies. That is hardly surprising, since it is very helpful for describing the social uses of nature, thus making it easier to bring sustainability issues into economic reasoning and political decision-making [35]. As such, capital natural is made up of all natural resources that humans employ for human ends. This usage is what makes nature a resource, despite the fact that sometimes nature performs functions for humans without even being touched (the satisfaction of aesthetic or moral needs, for instance). Properly speaking, natural capital is a meta-concept that identifies different functions and benefits that nature provides to humans [36].

Therefore, natural capital is not directly observable. It has to be humanly used as such to be included in that category. Likewise, particular materials or chemical processes might be excluded from such consideration for a long time, until a way of using them for human needs is discovered. Hence the contingency of nature as capital. On the other hand, usages can change or become multiple, as biofuels come to show. However, if such a wide concept is to be operational, it has to be refined by distinguishing between different subtypes of natural capital, as well as by sorting out their relative importance for human beings according to the usage they make of it.

Natural capital is thus a part of the capital on which human depend for surviving and thriving. Other forms of capital are human-made (comprising human creations and human capital itself) and cultivated ones (the latter encompassing domesticated animals, cultivated plants, and all kinds of manipulated beings and habitats) [37]. Both categories can also be unified under the label "manufactured capital". Ultimately, both human-made capital and cultivated capital depend on nature: either by using directly natural stuff or re-orienting living natural entities and components for human ends. Different socio-ecological regimes will use differently and in disparate degrees these varieties of capital.

Likewise, within natural capital writ large, the most relevant criterion for further distinctions is the relative importance of the contribution that different segments of the former make to human survival and welfare. Thus the distinction between disposable (irrelevant), fungible (important but not crucial), and critical (irreplaceable) natural capital. An important warning to be made is that irreversibility should not be conflated with criticality. They are two different qualities: the loss of a natural being or habitat may be irreversible, but not necessarily critical. Properly speaking, criticality should refer to those natural components or entities whose loss might seriously compromise human survival or means a severe curtailment of its welfare. They have to be irreversible and irreplaceable, the environmental functions they perform not being amenable to substitution by cultivated or human-made capital. Unfortunately, it is as of yet difficult to know for certain which ecosystems and functions are critical and which are not [38]. Moreover, the definition of critical natural capital relies not only on our capacity to supply factual knowledge about socio-ecological systems, but also on discussions about the values that underline our use of natural capital [39]. Thus, neither irreplaceability nor criticality is an absolute category.

Another way of looking at this problem is to distinguish between natural stocks and funds $[39,40]$. As their names suggest, stocks are consumed after being used, while funds can be used indefinitely. Whereas coal and oil belong to the former category and adopt the form of flows, the latter include living (air, water, sun) and non-living nature (plants or animals) that comes in the form of service provision. This should make it easier to measure irreversibility and irreplaceability. However, a relational approach incorporating ecosystems is advisable, since both flows and services depend on the systemic relacions that make up for the latter.

Yet an interesting addition to this taxonomy is provided by environmentalists who are worried about things other than human survival and welfare. Non-economic usages of nature should be added to the concept of natural capital, lest the reductionist view of neo-classical economics is reproduced [41]. Thus, if we leave functionality aside, what needs recognition is the intrinsic value of nature. The latter is represented by those natural units -whether beings or habitats- that represent unique ecological associations [42]. These units are like a living memory of natural evolution and as 
such not substitutable. Holland suggests calling them "units of significance" [42]. Their value lies in their meaning, a living meaning that disappears with them.

However, how are we going to decide? Where does the critical quality of natural capital lie? Is every natural form meaningful, or we have to choose between greater and lesser "meanings", due to the impossibility of protecting everything? A further distinction has to be introduced between goods, functions and services, as provided by natural systems. A good is resource provided by ecosystem components, whereas functions and services are structural conditions for human life and are performed by ecosystem processes [34]. In turn, four functions can be identified: regulation of ecological processes and systems of life support; production of raw materials, food, genetic resources; habitat provision, so that plants and animals have an habitat to live in, thus helping to preserve biodiversity; information functions that are related to moral or aesthetic human needs, as well as to the provision of research, cultural, or historical data. However, the latter category does not do enough to prevent the critique that the services argument cannot explain why those caring for nature want to preserve it and is thus ultimately harmful [43]. We will come back to this.

A particular sustainability will be defined by how it does decide upon the protection and management of these different categories of capital-their combination and reciprocal relations. This will produce a given level of human welfare, as well as a given degree of natural protection. However, being self-evident that some amount of natural capital is to be preserved, it is unclear which is the precise degree of protection that is required. There is no consensus on the right level of protection. If we could determine which assets are critical, in fact, there would be no conflict between different positions on substitutability whatsoever [44]. This is especially clear regarding information functions, since people may have different views about them, i.e., about the amount of nature that has to be preserved for them to be provided. The same goes for units of significance.

Moreover, the absence of scientific certainty about how much natural capital should be protected on account of its criticality just adds to the confusion. To suggest that a given amount of natural capital might be substituted is different than saying it must be kept at all cost. Usually this opposite views are summarized in the distinction between weak and strong models of sustainability. The weak ones accepts high rates of substitution, whereas the strong ones restrict the substitution of natural capital, thus enlarging the scope of criticality [45]. But it is impossible to know for sure which is right. A further, fundamental reason for that uncertainty is that we cannot know in advance what parts of nature that now seem to be critical or just important will be substitutable inb the future-so that, leaving normative claims and historical meanings aside, the irreversible natural capital of today may just be the disposable or fungible natural capital of tomorrow.

Somehow, sustainability studies assume a stable nature as an object of analysis and a measure for calculations regarding the provision of goods and the performing of functions and services to humankind. However, what if nature has changed? What if the process of hybridization that is the side-effect of the human colonization of nature has altered the workings of natural systems? What if the human ability to transform nature has fewer limits than expected?

\section{The Great Hybridization and Its Consequences}

The central claim in the Anthropocene hypothesis is that human beings have been a major agent in natural evolution, and increasingly so since the Industrial Revolution began. As a result, it has become more and more difficult to distinguish between societies and environments, since they have merged into a complex socionatural entanglement. This process of human colonization and appropriation makes sense from an evolutionary perspective. It is not thus an aberration, but the logical result of the aggressive adaptation that distinguishes the species way of being.

This historical process is also a process of hybridization by which nature is gradually losing its autonomy from society. Habitats, natural processes, animals become increasingly affected by human activity, irrespective of whether that influence is visible or not. It makes sense to see the Anthropocene as culminating The Great Hybridization of society and nature. Whereas the best metaphor for the 
human recombination is provided by Haraway's cyborg [46], natural hybridization has been defined by Latour a process by which nature is transformed into nature-culture objects resulting from social activities and practices [47]. This in turn means that assemblages are more important than ontologies, since the category of "the natural" becomes increasingly meaningless [48]. Moreover, the process by which hybridization is produced counts more than the hybrid itself [49], because the latter cannot be simply reduced to its components, but produces an emergent novelty whose qualities are the result of an association [50,51]. Old dualisms that separate nature from culture or the mind from the body are thus not the best tools to understand this new material reality.

It is the Anthropocene that comes to show that hybridization is the new normal. Ellis and Ramankutty have introduced the notion of "anthropogenic biomes" to describe the lack of "naturalness" of basic ecological units [52]. Natural purity was already under attack from cultural historians [53], but the idea that what looks like nature is nature remains firmly entrenched. That is wrong:

"Anthropogenic biomes are best characterized as heterogeneous landscape mosaics, combining a variety of different land uses and land covers. Urban areas are embedded within agricultural areas, trees are interspersed with croplands and housing, and managed vegetation is mixed with semi-natural vegetation (e.g., croplands are embedded within rangelands and forests)" [52].

This comes to demonstrate how the social and the natural are intermingled in a deep fashion all over the Earth, an embeddedness of ecosystems and social systems that actually "couples" them $[2,54]$. At the same time, new patterns of biodiversity are emerging, as this logic of intentional and unintentional recombination is intensified. Examples abound, from rocks made of plastics and corals in Hawaii to species invasions and alterations in phenotypic characteristics of exploited species $[53,55]$. Moreover, some talk of "Homogocene" to reflect how those species that best adapt to human systems become predominant over those specialist ones that have lived in isolation [56]. Others, though, make a different point, emphasizing how this general alteration in biodiversity will actually produce new habitats and species or put into contact species formerly separated [57]. Needless to say, this is of the utmost importance for any conception of sustainability that includes the preservation of natural forms among its goals: if it is not clear what is natural, or what does it mean to preserve original habitats, to decide upon how to organize conservation becomes more confusing in the Anthropocene. Classical environmental management does not look like a reasonable guide anymore [58]. Restoration is an increasingly meaningless notion, unless historical fidelity is taken as a guiding principle rather than a rigid goal [59] and new socioecological conditions are integrated into the analysis [60]. Leaving nature to restore itself isolating particular habitats from social contamination ("wild adaptation") [61] or reintroducing lost species in new environments ("rewilding) [62] have also been proposed as alternatives for a climate-changed world.

Yet there is a different pathway, namely that of forgetting about this old grammar and departing from the assumption that nature as it used to be does not exist anymore: natural spaces are entities that lie in the past and cannot be recovered. A shift should thus be fostered towards ecological design and management, a strategy of conservation that forgets about prehuman landscapes and goes for a more diverse and promiscuous human-nature entanglement that is, at the same time, more human-friendly [63]. However, the complexity of the Anthropocene should be kept in mind when dealing with this delicate issue, so that a case-by-case approach should be privileged lest we prevent ecosystems from performing their functions and providing their services. Intact ecosystems still active in remote areas, for instance, should be preserved [64]. Them aside, though, a postnatural ontology is the signature of the Anthropocene [65]. As Baldwin has suggested, nature is now but a socio-political sphere produced and made sense of thanks to technological and ideational practices [66]. Such view is now common within the social sciences [67].

To embrace the idea of the Anthropocene means thus to advance towards an understanding of nature that takes human influence on it seriously_before considering the moral implications of that 
influence. What the Anthropocene hypothesis states is that there is no way back for human beings, because we are not just embedded in nature, but also entangled with it in an irreversible and complex way. Sustainability is not, cannot be, what it used to be.

\section{Rethinking Sustainability in the Anthropocene}

In order to reflect on sustainability in the postnaural age, the classical distinction between weak and strong sustainabilities does not seem the most appropriate under the new light provided by the Anthropocene and the hybridization process it aptly summarizes. The main reason is that the latter is troublesome for a meaningful distinction between different types of capital. Despite its apparent clarity, categories such as human-made and natural capital serve to obscure a relational, bizarre material reality where mutual contamination and recombination are actually prevalent. It also creates a misunderstanding about the possibility to devise an ethics of substitutability or even about the feasibility of a strong sustainability. That is also why the notion of cultivated capital should be privileged in this context as the one that captures best the paradoxes of sustainability in the Anthropocene.

Sustainability involves designing a socionatural relation that can be maintained in the long term. It concerns that relation as such, but the latter are by definition dynamic and changing. But if human beings have become the main agent of change with the passing of time, how useful it is to employ the category of natural capital? Nature is a living and reproductive entity [68]. Nature is not to be seen anymore as an entity affected by the damaging influence of an external agent (humanity), but rather as a dynamic compound of influences of which human beings are an increasingly important one. There is even talk of "technonatures", a term that tries to convey the fact that this socionatural entanglement involve the mediation of diverse hybrid materialities and non-human [69].

Yet could it not be the case that substitutability itself has become a flawed category? As such, it presupposes the idea of nature being replaced by something made by humans. But what we find is rather the mixing of the natural and the social, their reciprocal assimilation. An alternative concept is that of "biofacts", describing entities originated or influenced by human activity or design, be the latter outwardly visible or not [66]. An important question is thus whether we wish to protect nature's integrity or just their apparent naturalness.

But the natural is not an absolute category, but a quality that can be measured in degrees. There is a genetic nature and a qualitative nature, as Dieter Birnbacher has argued: one is historial and alludes to the existence of nature without human intervention, the other is phenomenological and comprises the natural entities that can be affected by human activity [70]. Which one is to be protected? And what that does mean exactly? Three possibilities arise: (i) protecting environmental functions, which might entail preserving entire ecosystems or substituting them in different degreesm depending on their criticality; (ii) preserving nature in a genetic sense, that is, the integrity of beings and habitats and systems; or (iii) taking care of nature in a qualitative sense, which involves maintaining natural forms whichever it is the true anthropogenical impact that lies behind that appearance of naturalness.

These are the main dimensions along which a postnatural sustainabi lity should be defined. The discussion about different forms of capital, including subtypes of natural capital, must also relate to them. Apparently, we should pay attention to the environmental functions performed by nature as a whole, so that those that are essential to our welfare are sufficiently provided [33,71]. But if enough stock is to be preserved in order to guarantee the provision of those functions into the future, the question remains as to how much natural stock is that and of which kind. At this point, the multi-functionality of natural capital must be underlined. Pelenc and Ballet sum up this idea through a simple example:

"natural capital is multifunctional i.e., in certain situations it can provide several services simultaneously. For example, the flow of water in a river can provide biological services (the reproduction of fish), economic services (the fish can be caught or the flow can 
be used to produce hydroelectricity), and recreational services (bathing in the river). This multidimensional aspect of natural capital means that it is unlikely for manufactured capital to act as an appropriate substitute" [72].

Different forms of capital should thus be seen as complementary in producing human wellbeing [73]. For those who argue that those functions depend on the relations within and between ecosystems, replacements and substitutions are actually dangerous options. Moreover, due to our lack of knowledge about how natural systems function, we cannot know for certain what the effects of destroying natural capital will be on human well [74]. Therefore, the strong sustainability approach assumes that the substitutability between natural capital and other forms of capital should be strictly limited to the circumstances where the use of the services provided by natural capital does not lead to the irreversible destruction of this capital because its depletion cannot be compensated for by investing in other forms of capital [73].

However, we might very well develop the ability to replace those functions. What if today's irreversibility is tomorrow's replaceability? Substitutability would then be less a danger than a matter of choice: a choice involving a decision about the amount of nature that we wish to protect on grounds other than its contribution to human survival and welfare, i.e., aesthetical, moral, philosophical, and recreational. The moral one appears to be the strongest and is surely the one most clearly associated with environmentalism. It is ultimately a fairly simple one: nature should be conceived in non-instrumental terms. Were this rule to be followed, substitution would be severely restricted on ontological terms [75]. It is history and historical processes what matter accordingo to Holland, not the attributes displayed by a particular natural entity: meaning belongs to nature in a historic sense, irrespective of its external qualities [76]. That is, nature in a historic sense, irrespective of its external qualities. A theoretical path that leads to the ecocentric mandate according to which even when substitution is possible, should not be made [36]. According to this view, there is no such thing as a substitution-only a loss.

This moral position notwithstanding, the maing goal of a sustainable society is to maintain a durable socionatural relations into the future, not conservation as such. It may include conservation, trying to protect nature in either (or both) a historic or qualitative sense-but properly speaking it does not have to. Nothing prevents that a given sustainable society protects irreversible natural capital without doing the same with nature's "units of significance": the meaning could be lost while the functions are kept. Paradoxically, though, substitution might help to protect nature's intrinsic value, as in preserving whales by replacing whale oil with electric light.

Enters hybridization, though. Natural capital will arguably maintain its relevance for the time being, but it is important to take into account how much natural systems and processes have mixed up with social ones. Therefore, an enlarged conception of cultivated capital seems much more central to the discussion on sustainability in a postnatural age. This includes not only domesticated animals, as well as livestock, fisheries, and plants that are submitted to human control and breeding, but also reconstituted materials of any kind that involve a conscious human recombination of natural beings. Critical natural capital is by no means to be dismissed, partly because it possesses a great political value as a reminder of nature's otherness and intrinsic value. At the same time, though, it should be acknowledged that it is not a closed category: what is critical today might stop being so in the future on account of scientific and technnological innovations. Moreover, critical nature may also keep its functionality despite it being altered or intervened upon without being thoroughly substituted. It would thus not be less critical, but certainly less natural. It can become cultivated capital as well, since it is not ludicrous to expect that natural capital as such will be cultivated in the Anthropocene age: synthetic biology is just in its infancy. Sustainability in the Anthropocene will not be viable without science and technology acting as key facilitators of environmental adaptation.

By itself, this does not answer how much nature should be protected aside from that which is considered in a given moment unsubstitutable on account of its criticality as provider of basic environmental functions. There are two different questions at stake: the amount of nature that we 
have to protect and that which we would like to see preserved: whereas the former should be answered on technical grounds, the latter depends on normative judgments. And how do we answer the first one will most likely influence how do we answer the second. It is bound to be a complex, forever ongoing discussion. Conclusions will always be temporary, for at least two reasons.

Firstly, apparent limits to replaceability will be moved forward science and technology provides new solutions. Irreversible natural capital may turn into fungible or disposable one, so that the amount of nature deemed as critical may diminish with the passing of time. This likelihood introduces a key difference in the debate on sustainability, because the design of the latter will not depend on whether a particular version of it is feasible or not, but rather on whether it is desirable. Proponents of strong versions of sustainability may conflate these two sets of arguments: technical feasibility and moral desirability. In fact, they do just that whenever the cultural functions of the environment are taken as critical or certain technical limits are taken as absolute rather than contingent.

Secondly, social prevalent views on nature may very well change too, thus changing in turn a given consensus on how much nature should be protected. As Holland remarks, we may develop new assumptions about natural capital utility [42]. However, this value change could make the protection of qualitative nature more desirable. There is no reason to think that a greater substitutability (in technical terms) will necessarily diminish the preference for naturalness (in moral or aesthetical or recreational terms). In fact, there are reasons to think that both fondness for charismatic animals and for recreational nature (mountains, natural reserves, beaches) are strong incentives to protect nature in a qualitative sense-at least in a degree that makes the satisfaction of these human needs possible. Ironically, global tourism may help to preserve those landscapes that it came to endanger in the first place.

In sum, notions such as substitution and criticality, as well as the traditional distinction between two types of sustainability depending on whether it provides a strong or a weak defence of nature should not be taken for granted in a postnatural age. In the Anthropocene, the question of nature should be discussed in a framework that recognizes the fact of hybridization and gives a more prominent role to cultivated capital in an extended sense.

\section{Conclusions}

This paper has explored how the Anthropocene-namely, those insights about the current state of the socionatural relation that the Anthropocene hypothesis lays on the table-affects currents understanding of sustainability from the vantage point of environmental sociology, which also involves considering the impact of the Anthropocene for environmental sociology itself. In this regard, the discipline's self-perception has revolved around the distinction between an ecological paradigm and an anthropocentric one, the former trying to correct classical sociology's inclination to dismiss natural constraints in favor of a sociocultural determinism, behind which an anthropocentric worldview is discernible. However, the Anthropocene involves a restoration of human exceptionalism, by showing how the human species way of adapting to the environment is grounded on the ability to transform the latter through a process of niche construction that cultural transmission (between and through generations) provides with unparalleled potency. Nature's transformation and domination is thus not a choice or an evolutionary accident, but an expression of the species way of being. As a result, after the modern acceleration, further intensified after World War II, human colonization of nature has reached unprecedented degrees, ushering a process of socionatural hybridization that-leaving appearances aside-involves a ubiquitous social influence on natural forms, beings, and habitats. The corresponding plasticity of socionatural relations, made possible by scientific and technological intervention, should be taken into consideration when reflecting upon sustainability.

As for sustainability itself, this paper has argued that it cannot be conceived anymore as if hybridization and advanced technologies did not exist. Its reliance on the notion of natural capital should be disputed, since it is not clear for how long this category maintain will its vigor in the face 
of an increasing substitutability. It is rather manufactured capital, and above all cultivated capital (that which is based upon the intended hybridization of social and natural forms and beings), that should be put at the center of a reinvigorated, Anthropocene-friendly understanding of sustainability. However, this does not mean that those parts of nature that remain less touched by human influence or express the latter in less visible-more "natural" - ways (such as pets, landscapes, forests, and beaches) is to be abandoned to the hands of a destructive technology. On the contrary, there are good reasons to expect a further displacement of social values in the direction of preservation. Most likely, though, moral arguments will have less relevance than emotional, aesthetic and recreational ones. Furthermore, this preservation will not be accepted if it hinders current and future levels of welfare-global middle classes are on the rise. Thus it seems advisable that environmental sociology, as well as environmentalism writ large, exerts an Anthropocenic turn. Only by doing so will they remain relevant in the redefinition of socionatural relations and hence sustainability that is already taking place.

Conflicts of Interest: The author declares no conflict of interest.

\section{References}

1. Steffen, W.; Grinevald, J.; Crutzen, P.; McNeill, J. The Anthropocene: Conceptual and Historical Perspectives. Philos. Trans. R. Soc. 2011, 369, 842-867.

2. Liu, J.; Dietz, T.; Carpenter, S.R.; Alberti, M.; Folke, C.; Moran, E.; Pell, A.N.; Deadman, P.; Kratz, T.; Lubchenco, J.; et al. Complexity of Coupled Human and Natural Systems. Science 2007, 317, 1513-1516. [PubMed]

3. Ellis, E.; Goldewijk, K.; Siebert, S.; Lightman, D.; Ramankutty, N. Anthropogenic transformation of the biomes, 1700 to 2000. Glob. Ecol. Biogeogr. 2010, 19, 589-606.

4. Dunlap, R.E.; Marshall, C. Environmental sociology. In The Handbook of 21st Century Sociology; Bryant, D., Peck, D., Eds.; Sage: Thousand Oaks, CA, USA, 2006; pp. 329-340.

5. Catton, W.R.; Dunlap, R.E. Environmental Sociology: A new paradigm. Am. Sociol. 1978, 13, 41-49.

6. Murphy, R. Sociology and Nature; Westview: Boulder, CO, USA, 1996; p. 10.

7. Dunlap, R.E.; Martin, K.M. Bringing Environment into the Study of Agriculture. Rural Sociol. 1983, 48, 201-218.

8. Arias-Maldonado, M. Real Green. Sustainability after the End of Nature; Ashgate: London, UK, 2012.

9. Marx, K. Capital, Volume 1; Vintage: New York, NY, USA, 1976; pp. 283-290.

10. Foster, J.B. Marx's Theory of Metabolic Rift: Classical Foundations for Environmental Sociology. Am. J. Sociol. 1999, 105, 366-405.

11. Woodgate, G.; Redclift, M.R. New Developments in Environmental Sociology; Redflict, M.R., Woodgate, G., Eds.; Edward Elgar: Cheltenham, UK, 2005; pp. xv-xxvi.

12. Buttel, F.H. Classical theory and contemporary environmental sociology: Some reflections on the antecedents and prospects for reflexive modernization theories in the study of environment and society. In Environment and Global Modernity; Spaargaren, G., Mol, A.P., Buttel, F.H., Eds.; Sage: London, UK, 2000; pp. $17-39$.

13. Fischer-Kowalski, M.; Weisz, H. Society as hybrid between symbolic and material realms: Toward a theoretical framework of society-nature interaction. In Advances in Human Ecology; Freese, L., Ed.; JAI Press: Stanford, CA, USA, 1999; Volume 8, pp. 215-251.

14. Arias-Maldonado, M. Environment and Society. Socionatural Relations in the Anthropocene; Springer: Heidelberg, Germany, 2015.

15. Balée, W. Historical ecology: Premises and postulates. In Advances in Historical Ecology; Balée, W., Ed.; Columbia University Press: New York, NY, USA, 1998; pp. 13-29.

16. Balée, W. The Research Program of Historical Ecology. Annu. Rev. Anthropol. 2006, 35, 1-24. [CrossRef]

17. Laland, K.; Brown, G. Niche-construction, Human Behavior, and the Adaptive-Lag Hypothesis. Evol. Anthropol. 2006, 15, 95-104. [CrossRef]

18. Laland, K.; O'Brien, M. Cultural Niche-construction. An Introduction. Biol. Theory 2012, 6, 191-202. [CrossRef] 
19. Smith, B. Niche-construction and the behavioral context of plant and animal domestication. Evol. Anthropol. 2007, 16, 188-199. [CrossRef]

20. Kendal, J.; Tehrani, J.; Odling-Smee, F. Human niche-construction in interdisciplinary focus. Philos. Trans. R. Soc. B 2011, 366, 785-792. [CrossRef] [PubMed]

21. Isendahl, $\mathrm{C}$. The Anthropocene forces us to reconsider adaptationist models of human-environment interactions. Environ. Sci. Technol. Lett. 2010, 44, 6007. [CrossRef] [PubMed]

22. Fischer-Kowalski, M.; Haberl, H. Conceptualizing, observing and comparing socio-ecological transitions. In Socio-Ecological Transitions and Global Change-Trajectories of Social Metabolism and Land Use; Fischer-Kowalski, M., Haberl, H., Eds.; Edward Elgar: Cheltenham, UK, 2007; pp. 1-30.

23. Smith, N. Uneven Development: Nature, Capital and the Production of Space; Blackwell: Oxford, UK, 1984.

24. Castree, N.; Braun, B. The construction of nature and the nature of construction. Analytical and political tools for building survivable futures. In Remaking Reality: Nature at the Millenium; Braun, B., Castree, N., Eds.; Routledge: London, UK; New York, NY, USA, 1998; pp. 3-42.

25. Latour, B. We Have Never been Modern; Harvester Wheatsheaf: London, UK, 1992.

26. Irwin, A. Society, nature, knowledge: Co-constructing the social and the natural. In Sociology and the Environment: A Critical Introduction to Society, Nature and Knowledge; Polity: Cambridge, UK, 2001; pp. 161-187.

27. Russell, E. Evolutionary History: Uniting History and Biology to Understand Life on Earth; Cambridge University Press: Cambridge, UK, 2011.

28. Dunlap, R.E.; Catton, W.R. Which Function(s) of the Environment Do We Study? A Comparison of Environmental and Natural Resource Sociology. Soc. Nat. Resour. 2002, 15, 239-249. [CrossRef]

29. Field, D.R.; Luloff, A.E.; Krannich, R.S. Revisiting the Origins and Distinctions between Natural Resource Sociology and Environmental Sociology. Soc. Nat. Resour. 2013, 26, 211-225. [CrossRef]

30. Dobson, A. Justice and the Environment. Conceptions of Environmental Sustainability and Theories of Distributive Justice; Oxford University Press: Oxford, UK, 1998.

31. Baker, S. Sustainable Development; Routledge: London, UK, 2006.

32. Seghezzo, L. The five dimensions of sustainability. Environ. Politics 2009, 18, 539-556. [CrossRef]

33. Costanza, R.; Daly, H.E. Natural capital and sustainable development. J. Conserv. Biol. 1992, 6, 37-46. [CrossRef]

34. De Groot, R.S. Functions of Nature; Wolters-Noordhoff: Amsterdam, The Netherlands, 1992.

35. Ekins, P.; Simon, S.; Deutsch, L.; Folke, C.; de Groot, R. A framework for the practical aplication of the concepts of critical natural capital and strong sustainability. Ecol. Econ. 2003, 44, 165-185. [CrossRef]

36. Ott, K.; Döring, R. Theorie und Praxis Starker Nachhaltigkeit; Metropolis-Verlag: Marburg, Germany, 2004; p. 176.

37. Holland, A. Sustainability: Should we start from here? In Fairness and Futurity. Essays on Environmental Sustainability and Social Justice; Dobson, A., Ed.; Oxford University Press: Oxford, UK, 1999; pp. 46-68.

38. Dedeurwaerdere, T. Sustainability Science for Strong Sustainability; Edward Elgar: Northampton, UK, 2014.

39. Döring, R. Natural Capital—What's the difference? In Sustainability, Natural Capital and Nature Conservation; Metropolis-Verlag: Marburg, Germany, 2009; pp. 123-142.

40. Faber, M.; Proops, J.; Manstetten, R. Evolution, Time, Production and the Environment; Springer: New York, NY, USA, 1997.

41. Chiesura, A.; de Groot, R. Critical natural capital: A socio-cultural perspective. Ecol. Econ. 2003, 44, $219-231$. [CrossRef]

42. Holland, A. Natural Capital. In Philosophy and the Natural Environment; Atfield, R., Belsey, A., Eds.; Cambridge University Press: Cambridge, UK, 1994; pp. 169-182.

43. Deliège, G.; Neuteleers, S. Should biodiversity be useful? Scope and limits of of ecosystem services as an argument for biodiversity conservation. Environ. Values 2015, 24, 165-182. [CrossRef]

44. Atkinson, G.; Dietz, S.; Neumayer, E. Handbook of Sustainable Development; Edward Elgar: Cheltenham, UK; Northampton, UK, 2007; p. 4.

45. Neumayer, E. Weak versus Strong Sustainability: Exploring the Limits of Two Opposing Paradigms; Edward Elgar: London, UK, 2010.

46. Haraway, D. Simians, Cyborgs, and Women: The Reinvention of Nature; Routledge: New York, NY, USA, 1991. 
47. Latour, B. Politics of Nature. How to Bring the Sciences into Democracy; Harvard University Press: Cambridge, UK, 2004.

48. Latour, B. Reassembling the Social: An Introduction to Actor-Network Theory; Oxford University Press: Oxford, UK, 2005.

49. Swyngedow, E. Modernity and hybridity: Nature, Regeneracionismo, and the production of the Spanish waterscape, 1890-1930. Ann. Assoc. Am. Geogr. 1999, 89, 443-465. [CrossRef]

50. Hinchliffe, S. Geographies of Nature. Societies, Environments, Ecologies; Sage: London, UK, 2007; p. 51.

51. Bakker, K.; Bridge, G. Material worlds? Resource geographies and the "matter of nature". Prog. Hum. Geogr. 2006, 30, 5-27. [CrossRef]

52. Ellis, E.; Ramankutty, N. Putting people in the map: Anthropogenic biomes of the world. Front. Ecol. Environ. 2008, 6, 439-447. [CrossRef]

53. Corcoran, P.; Moore, C.; Jazvac, K. An anthropogenic marker horizon in the future rock record. Geol. Soc. Am. Today 2014, 24, 4-8. [CrossRef]

54. Cronon, W. Uncommon Ground. Rethinking the Human Place in Nature; W.W. Norton \& Company: New York, NY, USA, 1996.

55. Darimont, C.T.; Carlson, S.M.; Kinnison, M.T.; Paquet, P.C.; Reimchen, T.E.; Wilmers, C.C. Human predators outpace other agents of trait change in the wild. Proc. Natl. Acad. Sci. USA 2009, 106, 952-954. [CrossRef] [PubMed]

56. Rosenzweig, M. The four questions: What does the introduction of exotic species do to diversity? Evol. Ecol. Res. 2001, 3, 361-367.

57. Thomas, C. The Anthropocene could raise biological diversity. Nature 2013. [CrossRef] [PubMed]

58. Schlosberg, D. For the animals that didn't have a dad to put them in the boat: Environmental Management in the Anthropocene. In Proceedings of the ECPR General Conference Sciences Po, Bourdeaux, France, 4-7 September 2013.

59. Higgs, E. History, novelty, and virtue in ecological restoration. In Ethical Adaptation to Climate Change: Human Virtues of the Future; Thompson, A., Bendik-Keymer, J., Eds.; MIT Press: Cambridge, MA, USA, 2012; pp. 81-102.

60. Sandler, R. Global warming and virtues of ecological restoration. In Ethical Adaptation to Climate Change: Human Virtues of the Future; Thompson, A., Bendik-Keymer, J., Eds.; MIT Press: Cambridge, MA, USA, 2012; pp. 63-80.

61. Meiklejohn, K.; Ament, R.; Tabor, G. Habitat Corridors \& Landscape Connectivity: Clarifying the Terminology. Center for Large Landscape Conservation. 2009. Available online: http://www.twp.org/ sites/default/files/terminology\%20CLLC.pdf (accessed on 3 November 2010).

62. Monbiot, G. A Manifesto for Rewilding the World. 2013. Available online: http://pm22100.net/ 01_PDF_THEMES/98_Monbiot/130527_A_Manifesto_for_Rewilding_the_World.pdf (accessed on 1 December 2015).

63. Kareiva, P.; Robert, L.; Marvier, M. Conservation in the anthropocene: Beyond solitude and fragility. In Love Your Monsters. Postenvironmentalism and the Anthropocene; Shellenberg, M., Nordhaus, T., Eds.; The Breakthrough Institute: San Francisco, CA, USA, 2011; pp. 24-32.

64. Caro, T.; Darwin, J.; Forrester, T.; Ledoux-Bloom, C.; Wells, C. Conservation in the Anthropocene. Conserv. Biol. 2011, 26, 185-188. [CrossRef] [PubMed]

65. Barry, J.; Mol, A.; Zito, A. Climate change ethics, rights, and policies: An introduction. Environ. Politics 2013, 22, 361-376. [CrossRef]

66. Karafyllis, N. Biofakte-Versuch Über den Menschen Zwischen Artefakf und Lebewesen; Karafyllis, N., Ed.; Mentis: Paderborn, Germany, 2003; pp. 11-26.

67. Baldwin, A. The nature of the boreal forest: Governmentality and forest-nature. Space Cult. 2003, 6, 415-428. [CrossRef]

68. Biesecker, A.; Hofmeister, S. Starke nachhaltigkeit fordert eine Ökonomie der (Re)produktivität. In Die Greifswalder Theorie starker Nachhaltigkeit; Egan-Krieger, T., Schultz, J., Pratap, P., Voget, L., Eds.; Metropolis-Verlag: Marburg, Germany, 2009; pp. 169-192.

69. White, D.F.; Wilbert, C. Technonatures. Environments, Technologies, Spaces, and Places in the Twenty-First Century; Wilfrid Laurier University Press: Waterloo, ON, Canada, 2009; p. 6.

70. Birnbacher, D. Natürlichkeit; Walter de Gruyter: Berlin, Germany, 2006. 
71. Cleveland, C.J.; Hall, C.A.S.; Kaufmann, R. Energy and the US Economy: A biophysical perspective. Science 1984, 255, 890-897. [CrossRef] [PubMed]

72. Pelenc, J.; Ballet, J. Strong sustainability, critical natural capital and the capabilities approach. Ecol. Econ. 2015, 112, 36-44. [CrossRef]

73. Dietz, S.; Neumayer, E. Weak and strong sustainability in the SEEA: Concepts and measurements. Ecol. Econ. 2007, 61, 617-626. [CrossRef]

74. Brand, F. Critical natural capital revisited: Ecological resilience and sustainable development. Ecol. Econ. 2009, 68, 605-612. [CrossRef]

75. Neumayer, E. Human development and sustainability. J. Hum. Dev. Capab. 2012, 13, 561-579. [CrossRef]

76. O'Neill, J. Sustainability, welfare and value over time. In Governing Sustainability; Adler, W.N., Jordan, A., Eds.; Cambridge University Press: Cambdirge, UK, 2009; pp. 283-304.

(c) 2015 by the author; licensee MDPI, Basel, Switzerland. This article is an open access article distributed under the terms and conditions of the Creative Commons by Attribution (CC-BY) license (http:/ / creativecommons.org/licenses/by/4.0/). 